\title{
ARTICLES
}

\section{Constitutionalism in Eastern Europe: An Introduction}

\author{
Jon Elster $\dagger$
}

Since 1989, seven countries in Eastern Europe have undertaken the transition from one-party rule to constitutional democracy: Albania, Bulgaria, Czechoslovakia, Hungary, Poland, Romania, and Yugoslavia. Six of the seven are currently rewriting their constitutions. The exception is Hungary, although that country's constitution is very much a patchwork, and new constitutional efforts can be expected there, too, within the next few years. In addition, several of the constituent republics are writing or revising their constitutions, including the Czech and the Slovak Lands in Czechoslovakia and Croatia and Slovenia in Yugoslavia. Finally, the German Democratic Republic had made some progress toward creating a new constitution before the process was overtaken by unification. Altogether, therefore, we are dealing with at least a dozen constitution-making processes.

This wave of constitution-making is not altogether unique. In the late 1700s, the individual American states, the United States itself, and France enacted a series of democratic constitutions. The wave of revolutions in 1848 also included brief constitutional epi-

$\dagger$ Edward L. Ryerson Professor of Political Science, and Co-Director, Center for the Study of Constitutionalism in Eastern Europe, The University of Chicago.

In addition to the sources cited below, this article draws on information provided by correspondent members of the Center for the Study of Constitutionalism in Eastern Europe at The University of Chicago Law School: Wiktor Osiatynski (Warsaw), Andras Sajo (Budapest), Branko Smerdel (Zagreb), Peter Kresak (Bratislava), David Franklin (Prague), Vojtesh Cepl (Prague), Krenar Loloçi (Tirana), Gueorgui Poshtov (Sofia), and Gyorgy Frunda (Bucharest). I am also indebted to discussions with Stephen Holmes, Aanund Hylland, Adam Przeworski, and Cass Sunstein. 
sodes. After World War I, many of the Central and Eastern European states set up new constitutions that, with the exception of Czechoslovakia, were not destined to last for long. After World War II, Italy, West Germany, and Japan created democratic constitutions. ${ }^{1}$ In the 1960s, a number of former British and French colonies in Africa became independent and enacted new constitutions. In the mid-1970s, Greece, Portugal, and Spain created new constitutions that broke with the authoritarian past. ${ }^{2}$

Such precedents notwithstanding, the current wave stands out in the following respects. First, all these countries have emerged from communist rule. Second, they all have pre-communist constitutional traditions. ${ }^{3}$ Third, along with political modernization, they are all undertaking simultaneous transitions from central planning to a market economy. ${ }^{4}$ Fourth, the histories of the countries are tightly intertwined, creating a stock of common memories-and common animosities. ${ }^{5}$ Finally, the developments of 1989 can be seen as a snowballing process in which events in one country inspired and accelerated those in others.

Although both similar and interconnected, the countries and their paths to democracy also differ in a number of ways. Czechoslovakia and Yugoslavia are federally organized, whereas the other five countries have a unitary state. Czechoslovakia, Hungary, and Poland are in some vague yet recognizable sense more advanced-both economically and culturally-than the group of Balkan countries. An important explanatory variable may be the degree of repression during communist rule. On this scale, the countries may be tentatively ranked in the following order, from

1 For good studies of the West German and Japanese cases, see Peter H. Merkl, The Origin of the West German Republic (Oxford, 1963); Kyoko Inoue, MacArthur's Japanese Constitution (Chicago, 1991).

2 For a good study of the Spanish case, which also provides useful comparative perspectives, see Andrea Bonime-Blanc, Spain's Transition to Democracy: The Politics of Constitution-making (Westview, 1987).

3 True, with the exception of Czechoslovakia, none of the countries enjoyed constitutional democracy over the whole period between the two wars. Nevertheless, the constitutions that were in effect during part of this period remain important models and sources of inspiration for today's constitution-makers in Bulgaria, Czechoslovakia, Poland, and Romania. See notes 69-70 and accompanying text.

- For an analysis of the problems posed by this simultaneous transition, see Adam Przeworski, Political and Economic Reforms: Democracy and Market in Eastern Europe and Latin America ch 4 (Cambridge, forthcoming 1991). For a brief discussion of the interaction between economic and political transition see also Jon Elster, When Communism dissolves, London Rev Books 3, 4-5 (Jan 25, 1990).

- A good overview of the whole region, with emphasis on the shifting traditions of conflicts and alliances, is Henry Bogdan, Histoire des pays de l'Est (Perrin, 1990). 
less to more severe: Poland, Hungary, Yugoslavia, Bulgaria, Albania, East Germany, Czechoslovakia (after 1968), and Romania. ${ }^{6}$ In all countries, the issue of ethnic, linguistic, or religious minorities is important, but the patterns differ dramatically. ${ }^{7}$ In Bulgaria, Hungary, Poland, Czechoslovakia, and East Germany, the transition to democracy was negotiated through Round Table Talks (RTT), whereas Romania, Albania, and Yugoslavia followed different paths.

Under these conditions, the constitution-making processes in Eastern Europe amount to a gigantic natural experiment. The countries in question present an optimal degree of diversity for comparative analysis: they are neither too similar nor too different. The focus of comparison is twofold. On the one hand, one can examine the processes of constitution-making. On the other hand, one can study and compare the outcome of these processes. My main interest, as a political scientist, is in the former issue: the blend of arguing and bargaining, threats and warnings, appeal to tradition, borrowing from abroad, and influence of extra-constitutional forces that characterizes the processes now under way in Eastern Europe. ${ }^{8}$ First, I will give a brief overview of the nationalist, linguistic, and religious dynamics of the region that pervade the reform process. Then I will sketch out the events that led up to the current wave of constitution-writing, focusing on the conditions that made reform possible and on the processes by which the countries moved away from communist rule. Finally, I shall consider the constitution-making efforts in the various countries, with special emphasis on the issues being discussed and the processes being used to reach decisions on those issues.

\footnotetext{
- Given the multi-dimensionality of oppression, a ranking of this sort may be close to meaningless. The complexity of the historical record provides an additional reason for being skeptical. I believe, however, that it is important to reflect on this issue. The perceived brutality of the former regime will determine how much opposition there will be to the former elite obtaining positions of economic privilege. It will also determine the strength of claims for retribution against that former elite as well as the risk and scope of witch hunting. One should not automatically assume that these problems will be less serious in the "advanced" countries than in the "backward" ones. It might seem surprising to rank Czechoslovakia above Bulgaria and Albania on the scale of repression. I am not claiming, however, that there was more tolerance of opposition in those countries; rather, there was less oppression because there was less opposition.
}

' See notes 9-14 and accompanying text.

- For a fuller discussion, see Jon Elster, Born to be Immortal: The Constitution-Making Process (Cooley Lectures, University of Michigan, Apr 15-17, 1991) (on fle with U Chi L Rev). 


\section{An Overview of the Region: Nationalism, LANGUAGE, AND RELIGION}

All over Eastern Europe, ethnic, linguistic, and religious issues are matters of intense conflict. They inform all political decisionmaking. In the constitutional context, they impinge on the organization of individual rights, and-in the federal countries-on the organization of government. To some extent, these conflicts are over clear-cut issues such as the right to use one's own language in dealings with the administration. More frequently, however, the strife is largely symbolic and historical in character. The conflicts between Czechs and Slovaks or between Serbs and Croats do not arise because one of these groups interferes with the exercise of the linguistic or religious rights of the other. ${ }^{9}$ Rather, they are caused by hostility and suspicions that go back for decades, centuries, or even millenia.

To impose some structure on the problem, let us define a $n a-$ tion as a political entity that is recognized by other countries and by international organizations; a republic as a political entity that has some autonomy (minimally defined by having its own constitution and assembly) within a nation; and a people as a community with common traditions, common language, common religion, and-perhaps most important-common enemies. A political entity (nation or republic) is homogeneous if (i) it contains only one people and (ii) negligibly few members of that people live outside the entity. It is internally heterogeneous if it contains non-negligible numbers of members of several peoples, and externally heterogeneous if it has one dominant people, and non-negligible numbers of that people live outside its borders. Tentatively, I suggest the hypotheses that internal heterogeneity is divisive, while external heterogeneity is unifying. ${ }^{10}$

In Eastern Europe, Poland is the most internally homogeneous country, with Poles making up 95 percent of the population. ${ }^{11} \mathrm{~A}$ vocal minority of 250,000 Poles lives in Lithuania; otherwise, Poland is externally homogeneous.

- An exception is the complaint by Croats that Serbs use their clout over state television to broadcast the most popular American programs with Cyrillic subtitles.

${ }^{10}$ Evidence for the first hypothesis is provided in Alvin Rabushka and Kenneth A. Shepsle, Politics in Plural Societies: A Theory of Democratic Instability (Charles Merrill, 1972). Evidence for the second might be found by looking at the role of Alsace-Lorraine in French politics between 1871 and 1914 or that of Rhineland in German politics after 1918.

11 The following data are taken from Vladimir V. Kusin, The Ethnic Factor, Report on Eastern Europe 34 (Nov 9, 1990). 
Hungary is externally heterogeneous: two million Hungarian speakers live in the Transylvanian region of Romania, some 600,000 in the Slovak Lands of Czechoslovakia, and about 500,000 in Yugoslavia. Altogether, almost 30 percent of the Hungarianspeaking population lives outside Hungary. Internally, Hungary is fairly homogeneous: about 93 percent of the population has Hungarian as their main language.

Albania, too, is externally heterogeneous, with 1.8 million speakers of Albanian in Kossovo (a region of Yugoslovia), some in other parts of Yugoslavia, and some in Greece. The Albanian Republican Party (the second largest party in the opposition) has unification of all Albanians as its main program, with an eagle with one wing clipped as its emblem. About 93 percent of the population in Albania has Albanian as its main language.

Romania is externally heterogeneous: the Soviet Republic of Moldavia is 65 percent ethnic Romanian and might join Romania were it to become independent from the Soviet Union. Romania is also internally heterogeneous, containing about two million Hungarians (10 percent of the total population).

Bulgaria is internally heterogeneous, containing about a million Turkish-speaking Muslims (about 10 percent of the total population) and 200,000 Bulgarian-speaking Muslims.

Czechoslovakia is internally heterogeneous, with five million Slovaks and ten million Czechs. The Czechs and Slovaks are divided partly by religion (Catholicism is more important in Slovakia) but mainly by historical traditions. As indicated above, Slovakia is itself internally heterogeneous due to a sizeable ethnic Hungarian population. Within the Czech Lands, there is also some opposition between Bohemia on the one hand and Moravia and Silesia on the other. This split has led to the suggestion to create a tripartite federal republic, which would be less likely to tear itself apart than a bi-republican state.

Yugoslavia is the most internally heterogeneous country in Eastern Europe, with divisions along linguistic as well as religious lines. Thus the 1.7 million Slovenes and 4.4 million Croats have the same religion, but different languages; the Croats and the eight million Serbs have the same language but different religions (and a tradition of violent conflict); and of the more than four million Muslims, half speak Albanian (in Kossovo) and half speak Serbocroatian (in Bosnia). Serbia is both internally heterogeneous (due to the Albanians in Kossovo) and externally heterogeneous (due to the 600,000 Serbs in Croatia). Kossovo itself has a 10 per- 
cent Serbian minority, which is therefore a subgroup within a subgroup within a subgroup of Yugoslavia.

An important variable is the geographical distribution of ethnic groups within the various regions. Members of the Turkish minority in Bulgaria are a majority of the population in the communities where they live. By contrast, the Serbs in Croatia and the Hungarians in Transylvania rarely form more than 50 percent of their local communities. ${ }^{12}$ Such variations in density constrain the demands that minority groups can plausibly make. These demands can range from secession to linguistic autonomy.

Often, the most explosive political issue is not that of minorities, but that of minorities within minorities. Indeed, alliances may arise between a majority and a minority-within-a-minority even when they belong to different groups. For example, the Hungarians in Slovakia and the Czech majority both opposed attempts to make Slovak the compulsory language in official dealings in Slovakia. The alliance is obviously more likely to emerge if the majority and the minority-within-a-minority belong to the same group, as in the relation between Serbia and the Serbs in Kossovo.

There are two ways, then, in which the geographical distribution of minorities can be an obstacle to their demands for self-determination. The presence of minorities within minorities ensures that a republic will meet internal resistance if it tries to declare itself autonomous, in addition to the predictable external resistance. This problem is illustrated by Kossovo. The presence of lowdensity minorities excludes territorial reorganization as a solution, as illustrated by the Serbs in Croatia. In such cases, the only "solutions" are mass migration, mass deportation (such as those carried out in many Eastern European countries after World War $\mathrm{II}^{13}$ ), or genocide.

Gypsies play a special role in Eastern Europe. ${ }^{14}$ Because of their mobile way of life, they are hard to count and not well-organized. Official figures have been much too low. In Romania, estimates of Gypsy population now range from one to three million. Czechoslovakia, Hungary, and Bulgaria may each have 700,000 or more. Gypsies present a growing problem, as their natural rate of increase is much higher than that of most other groups.

\footnotetext{
12 Bogdan, Histoire des pays de l'Est at 497 (cited in note 5); see also Trond Gilberg, Nationalism \& Communism in Romania 167 (Westview, 1990).

${ }^{13}$ Bogdan, Histoire des pays de l'Est at 390-92 (cited in note 5).

14 The following draws on Simon Simonov, The Gypsies: A Re-emerging Minority, Report on Eastern Europe 12 (May 25, 1990).
} 
In some countries, the minorities are economically worse off than the majorities. This is the case, notably, of the Slovaks in Czechoslovakia and the Serbs in Croatia. In other countries the minorities, even if not actually better off today, might have a greater wealth potential in a market economy. The Turkish minority in Bulgaria has an advantage by virtue of cultivating the fertile tobacco lands in the South. Hungarians in Transylvania claim that their greater entrepreneurial skill will enable them to rise to the top. Each case-poor minorities and rich minorities-could exacerbate social conflicts.

The hypothesis that internal heterogeneity is divisive is amply confirmed in Romania, Bulgaria, Czechoslovakia, and Yugoslavia. The hypothesis that external heterogeneity is unifying seems to receive some confirmation in Serbia and in Albania. In addition to the passions generated by ethnic cleavages, two other sources of social conflict should be mentioned. First, in almost all Eastern European countries there are or are likely to be demands for retribution against the former nomenklatura. These demands will be reinforced if, as is happening in several countries, the former communists also turn out to be the new economic elite. Second, any economic elite is likely to be met with resentment and suspicion. It may well turn out that the most lasting legacy of communism will be a deep-seated egalitarian feeling in the population. Political developments all over Eastern Europe are likely to be heavily shaped by this potent mix of hatred, vengefulness, and envy.

\section{The Road to Democratic Reform}

\section{A. The Preconditions}

One can argue (but hardly prove) that the emergence of constitutional or constitution-making democracies in Eastern Europe was the outcome of three independent causes, none of which was sufficient but each of which was necessary.

First, Gorbachev's triple policy of glasnost, perestroika, and non-interference (abandonment of the Brezhnev doctrine) was a crucial factor. In East Germany, the population must have perceived that the communist regime was in trouble when the government banned Soviet magazines from the newsstands. The "ecoglasnost" movement that was at the origin of reform in Bulgaria clearly drew on the Soviet experience, as a source of legitimacy if not of inspiration..$^{15}$ More importantly, of course, Gorbachev sent a

${ }^{15}$ It is worth noting that environmental groups were also at the origin of the radicalization of the Hungarian opposition. See Laszlo Bruszt and David Stark, Remaking the Politi- 
signal not only to the East Germans but to all Eastern European countries when, during the celebrations of the fortieth anniversary. of the German Democratic Republic, he told Erich Honecker that "[t]hose being late will be punished by life itself"-an apparent reference to political and economic reforms. ${ }^{16}$ Before that date-October 7, 1989-there was room for genuine fear of Soviet intervention. During the Polish RTT, for instance, Geremek rejected the proposal for completely free elections on the grounds that it was too radical for the Soviets. ${ }^{17}$ After Gorbachev's speech, the fear of Soviet intervention rapidly abated, especially as mass rally after mass rally, in country after country, went unpunished.

The second independent mover of events was the set of Round Table Talks in Poland. First, they created a model for informal talks between the regime and the opposition for other countries to follow. In the Hungarian RTT, for instance, the opposition was in contact with its Polish counterparts. In addition, the elections following the Polish RTT must have had an immense, demoralizing effect on the communist regimes in other countries. Finally, the fact of Soviet non-intervention created a new set of prior expectations for the subsequent transitions.

A third and less well-known factor was the ironic causal circle beginning and ending in Romania. ${ }^{18}$ Ceaucescu's brutal treatment of the Hungarian minority created a constant pressure on the border towards Hungary. Until June 1989, Hungary refused to accept the Romanians who escaped across the border. When the Hungarian authorities changed their policy, they soon discovered that taking in refugees is costly and applied to the United Nations for financial aid. The Hungarians received the aid on the condition that they sign the UN Convention on Refugees, which requires states to harbor refugees who may face persecution in their home country. That convention, however, was incompatible with Hungary's bilateral agreement with East Germany that required each state to extradite to the other those charged with criminal behav-

cal Field in Hungary: From the Politics of Confrontation to the Politics of Competition, in Ivo Banac, ed, Eastern Europe in Revolution (Cornell, forthcoming 1991).

${ }^{16}$ Serge Schmemann, Security Forces Storm Protesters in East Germany, NY Times Al (Oct 9, 1989).

${ }^{17}$ Wiktor Osiatynski, The Round Table Negotiations in Poland 34 (Working Paper, Center for the Study of Constitutionalism in Eastern Europe, The University of Chicago Law School, 1991).

${ }^{18}$ I am indebted to Wiktor Osiatynski for pointing to this mechanism. See Wiktor Osiatynski, Revolutions in Eastern Europe, 58 U Chi L Rev 823, 838 (1991). 
ior, such as illegal border crossings. ${ }^{19}$ Thus, when the East German refugees arrived at Hungary's border soon after the Romanians, Hungary decided to admit them and let them leave for Austria on their way to West Germany. The ensuing exodus was a major factor in the downfall of the East German regime. The next domino to fall was Czechoslovakia in November 1989, and with the fall of Ceaucescu in December, events had come full circle.

\section{B. The Transition}

In five of eight countries (including East Germany), the transition to democracy was negotiated through RTT between the Communist Party ${ }^{20}$ (together with various satellites and pseudo-independent organizations) and a more or less well-organized opposition. I shall consider the transition in these countries first, and then turn to the transition in the other countries.

\section{The Round Table Talks.}

The outcome of the talks shaped the constitutional developments in two ways. First, the agreements reached on electoral laws in several cases shaped the composition of the constituent assembly. Second, constitutional revisions agreed upon in the RTT may survive in later constitutions. Rather than recounting the story of each RTT, ${ }^{21}$ I shall point out some salient similarities and differences.

A classical framework for comparing the conduct of the RTT in each country is a four-actor model. ${ }^{22}$ Within the regime, there

10 Radio Free Europe Background Report 139 (Aug 4, 1989).

20 To facilitate the task of the reader, I refer to "the Communist Party" even when the official name of the party was or is different (many of the communist parties changed their name during the transition). I am also assuming, somewhat controversially perhaps, that the National Salvation Front in Romania is little more than a continuation of the former Communist Party.

${ }^{21}$ For details of the RTT in Hungary, see Brusz: and Stark, Remaking the Political Field in Hungary (cited in note 15), as well as Andras Sajo, Round Tables in Hungary (Working Paper, Center for the Study of Constitutionalism in Eastern Europe, The University of Chicago Law School, 1991). For Poland, see Osiatynski, The Round Table Negotiations in Poland (cited in note 17). For East Germany, see Ulrich Preuss, The (Central) Round Table in the Former German Democratic Republic (Working Paper, Center for the Study of Constitutionalism in Eastern Europe, The University of Chicago Law School, 1991), as well as Uwe Thaysen, Der Runde Tisch Oder: Wo blieb das Volk? Der Weg der $D D R$ in die Demokratie (Westdeutscher Verlag, 1990). The Center for the Study of Constitutionalism in Eastern Europe will issue a Working Paper by Rumyana Kolarova and Dimitr Dimitrov on the RTT in Bulgaria.

${ }^{22}$ See notably Przeworski, Political and Economic Reforms at ch 2 (cited in note 4). 
can be hardliners and reformers. Within the opposition, there can be moderates and radicals. The real negotiations take place between reformers and moderates. Hardliners and radicals are "quasi-actors" rather than full-fledged strategic actors: they serve as resources for, respectively, reformers and moderates. At any given point in the negotiations, one party may refer to its more extreme allies when issuing threats or warnings, where threats take the form of "if you do X, I shall make my allies do Y," and where warnings take the form of "if you do X, my allies will do Y." Many statements issued as warnings are, of course, threats in disguise. And to the extent that the statements genuinely are warnings, they may be true by virtue of prior actions taken for the purpose of making them true. In this case, we may refer to them as pseudowarnings. When the Communists say "If you do X, the Soviets will come," they may really mean "If you do X, we shall ask the Soviets to come." When the moderates in opposition say, "If you do X, our radical faction will take to the streets," the warning may be true by virtue of earlier, inflammatory statements issued for this purpose. We need to distinguish, in other words, between four cases: (i) Genuine threats: If you go in that direction, I shall fire a shot that will wake up a lion that will kill you; (ii) Genuine warnings: If you go in that direction, you will wake up a lion; (iii) Disguised threats: If you go in that direction, my hot-tempered friends will fire a shot that will wake up a lion; and (iv) Pseudo-warnings: If you go in that direction, you will wake up a lion that I put in place there last night.

The Polish RTT were the only talks with the full complement of actors. In Bulgaria, there were only two actors: the hardliners had been eliminated by the time the RTT began, and the opposition had too little structure to allow for a differentiation between moderates and radicals. Although the Bulgarian opposition could and did play on the threat or warning of mass demonstrations, those who took to the streets did not constitute an organized faction with well-defined aims of its own.

In Hungary, the transition involved three actors: hardliners, reformers, and a fairly undifferentiated opposition. Although the groups in the opposition did break up toward the end of the talks, they succeeded in preventing the regime from manipulating and exploiting their internal differences. In the Czechoslovak and East German RTT, the process was not so much one of negotiation as one of unilateral imposition: there was only one actor-the unified opposition. 
Stepping outside the four-actor model, Western governments played an important role in the Polish and Hungarian cases. A major reason why the Polish Communist Party wanted negotiations in the first place was the need for Western credit, which they could not get unless Solidarity helped them to provide a minimal level of democratic legitimacy. ${ }^{23}$ In Hungary, the strategy of the hardliners was constrained for similar reasons. ${ }^{24}$

Not surprisingly, the different mix of actors yielded different outcomes from the RTT. In Poland, for example, the Communist Party obtained a guarantee that Jaruzelski would become president, regardless of electoral behavior. There were to be free elections to a newly created Senate with 100 Senators. The communists and their allies were guaranteed 65 percent of the members in the 460-member Sejm (lower house). In this way, the communists were also guaranteed a majority (299 members out of 560) in the joint sessions of the two houses that was to elect the president by simple majority. Although the communists were not guaranteed the two-thirds majority in the Sejm needed to overrule a veto of the Senate, they no doubt thought they would get the extra eight seats that were needed. In the end, they did not get a single nonguaranteed seat in the Sejm and received only one seat in the Senate. Although this worst-case scenario had been built into the compromise, its realization came as a shock. In reality, therefore, the RTT agreement was built on a miscalculation.

In Bulgaria and Hungary, the outcome of the RTT was a set of electoral procedures that might benefit the Communists, but only given certain (fallible) assumptions about political behavior. Consider first Bulgaria. In almost all Eastern European countries (today's Poland is an exception), the communist parties have advocated majority vote in single-member districts, because their candidates are believed to have higher recognition, whereas the opposition has advocated proportional voting. The Bulgarian compromise was to let each voter have two votes, one to be cast in single-member districts and one to be cast for party lists in 28 constituencies. In the negotiations over the presidency, the Commu-

\footnotetext{
2s Abstractly, then, the question may be put in terms of three levels of Solidarity participation in politics: (i) the minimal level that would satisfy the Western governments, (ii) the minimal level that would satisfy Solidarity members that they were not selling out to the Party, and (iii) the maximal level that could satisfy the Party that their monopoly on power was not in real danger. One interpretation of the events could be that the Party believed that iii $>$ ii $>$ i, whereas in reality it turned out that $\mathrm{ii}>$ iii $>$ i.

${ }^{24}$ According to Bruszt and Stark, Remaking the Political Field in Hungary (cited in note 15), foreign labor organizations, including the AFL-CIO and the U.S. Department of Labor, helped to thwart the hardliners' attempts to restrict union activity in Hungary.
} 
nists wanted a popularly elected president, since they (wrongly) believed that the elections to parliament would leave them in a minority, whereas they might be able to win a majority in presidential elections. They also, therefore, wanted very strong powers vested in the head of state. The compromise reached was to have a Communist president elected by the Assembly, but with relatively weak powers.

In Hungary, a similar although more complicated compromise was reached on the electoral system. ${ }^{25}$ In addition, there was an agreement to have early presidential elections, in which everybody believed that the Communist candidate Imre Pozsgay would win. The agreement, however, was undermined by a disastrous miscalculation made by the Communist Party: when it dissolved itself to create a new socialist party, only a small fraction of the former members joined up. The demoralizing effect of this event was similar to that of the poor electoral show of the communists in Poland.

In Czechoslovakia and East Germany, the RTT essentially produced a civilized and total capitulation of the communist regimes, with no concessions given to the former elite.

\section{Non-RTT countries.}

Romania was the only country in which the transition occurred through a violent revolution. The later preparation of the first free elections (in May 1990) was managed unilaterally by the National Salvation Front, which also received a large majority in parliament.

Albania is also unique, in that the country's first free elections on March 31, 1990 were organized by the Communist Party without any prior negotiations with the opposition. The elections gave a Communist majority ( 168 members out of 250 ) in the new parliament. The electoral system (adopted by the communists before the introduction of a multi-party system) was a variant of majority voting with run-offs. The Democratic Party (the main party in the opposition) originally fought for proportional voting, but later, as they gained in confidence, accepted the majority system.

In Croatia, the decision to hold multi-party elections was made in December 1989-January 1990. Formally, the decision was taken by the Communist Party, but under strong pressure from

25 John R. Hibbing and Samuel C. Patterson, A Democratic Legislature in the Making: The Historic Hungarian Elections of 1990, Yearbook of the Hungarian Political Science Association 128 (1990). 
mass demonstration and under the impact of the ongoing Romanian revolution. The task of drafting the electoral law was turned over to a committee of experts. The outcome of the election in April 1990 has been characterized as a "plebiscite against the communist rule, ${ }^{\prime 26}$ with the Communists receiving about a quarter of the votes and of the seats in parliament.

\section{The Constitution-Making Process}

The initial movement away from communist control toward democracy was just a beginning. The countries now face the task of creating a blueprint for a stable democratic system. The following section will first provide an overview of the various countries and their progress toward creating a constitutional document. Then it will turn to a general discussion of the issues that all countries face and the decisionmaking processes that they have adopted to settle those issues.

\section{A. An Overview of the Various Constitutions}

\section{Albania.}

The official Albanian constitutional draft, which will become final if it garners the support of two-thirds of parliament, contains the following provisions, among others. First, the workers have the right to strike, but only when their legal rights are violated. In Western systems, of course, this is precisely the case in which they would not strike but instead address themselves to the courts. The past also survives in a clause to the effect that educational standards must be in compliance with a materialistic world outlook. With regard to the executive, the president is elected by the Assembly (by secret ballot and a two-thirds majority) and invested with important powers, including the authority to set aside government decrees as unconstitutional. This clause was probably written with the current President Alia in mind. ${ }^{27}$ The president and the parliament are elected for five and four years respectively, thus

\footnotetext{
28 Branko Smerdel, Constitutional Developments in Croatia and Yugoslavia 1989-1991 (Report to the Center for the Study of Constitutionalism in Eastern Europe, The University of Chicago Law School, Feb 1991) (on file with U Chi L Rev).

27 Although Alia was defeated in the elections to Parliament on March 31, 1991, the constitutional draft does not require the president to be a member of parliament. Albania Leader Loses Parliament Seat, Chicago Tribune $\S 1$ at 3 (Apr 1, 1991). I have not had access to a full translation of the draft. This summary is based on the (very) partial translation in Louis Zanga, Mixed Fortunes as the New Year Begins, Report on Eastern Europe 1 (Jan 18, 1991).
} 
creating the possibility of "cohabitation." Given that the Communists gained one more seat than a two-thirds majority necessary to adopt the constitution, they will be able to adopt it if they remain united.

\section{Bulgaria.}

The Grand National Assembly (Constituent Assembly) has 18 months, from June 1990, to vote in a new constitution, which will have to be adopted by a two-thirds majority. Although debates in the Assembly have barely begun, about a dozen different constitutional drafts have been presented. ${ }^{28}$ The draft written by a member of the U.S. Chamber of Commerce is modeled on the U.S. Constitution and contains very stringent amendment procedures. The draft submitted by a group of young, liberal lawyers would grant strong powers to the president. A draft presented by a member of parliament from the Union of Democratic Forces (the main oppositional coalition) would grant strong powers to the Constitutional Court. A draft presented by the Bulgarian Social Democratic Party (a tiny non-Marxist party) contains various illiberal clauses such as the obligation to work and freedom of speech restricted by "good manners." A draft by the Bulgarian Agrarian Union (a pseudo-independent ally of the Communists) emphasizes positive rights and restricts personal freedoms. A draft by an independent member of parliament would give strong powers to the president. And finally, a draft presented by the Bulgarian Socialist Party (the former Communist Party) proposes a popularly elected president with weak prerogatives, together with various restrictions on the freedom of speech and assembly.

According to observers, there seems to be general agreement on a strong President, who would appoint the prime minister; and on a unicameral assembly. Also, it is likely that parties based on ethnic, linguistic, and religious criteria will be prohibited, as all the drafts contain clauses to that effect. ${ }^{2 \theta}$

\footnotetext{
${ }^{28}$ The following draws on Gueorgui Poshtov, Constitutional Debates and Constitutional Changes in Bulgaria (Working Paper, Center for the Study of Constitutionalism in Eastern Europe, The University of Chicago Law School, Jan 30, 1991); Kjell Engelbrekt, The Grand Assembly to Adopt a New Constitution, Report on Eastern Europe 5 (Apr 19, 1991).

29 The prohibition may or may not affect the Movement for Rights and Freedoms, a party with 23 members in the Grand Assembly. Although running on a prima facie neutral platform, the Movement is the de facto party for the Turkish minority.
} 
3. Czechoslovakia.

The Federal Assembly is currently engaging in patchwork revisions of the Constitution. ${ }^{30}$ At the same time, a constitutional committee in the Assembly is drafting a whole new charter, to be adopted before June 1992, that will incorporate some or all of the earlier patchwork revisions. The Assembly has already adopted a provisional bill of rights. The Czech and Slovak National Councils have also appointed committees to draft new constitutions within the same time limit. ${ }^{31}$ The most important issue facing the Czechoslovak constitution-writers is the relation between the federal and the republican levels of decisionmaking. In this context, the role of the 1968 Communist Constitution has turned out to be crucial. ${ }^{32}$ Under that document, a certain pre-defined category of important laws must garner a simple majority both in the 200-member lower house (elected by proportional voting) and in each of the equalsized Czech and the Slovak sections of the 150-member upper house. Constitutional changes have to pass by a three-fifths majority in the same way. Thus, in theory, 31 members of the upper house could block all constitutional changes.

Although never implemented under communist rule, this procedure has now become very important. It obviously confers great powers on the Slovak deputies. By virtue of their constitutionmaking clout, the Slovaks are demanding and getting parity of power in a number of federal organs. ${ }^{33}$ The governor of the central bank will rotate annually between the republics. The constitutional court will have six members from each republic. The Slovaks have also succeeded in shifting a number of responsibilities from the federal to the republican governments, although the provisional agreements that have been reached often suffer from a great deal of (probably deliberate) ambiguity. ${ }^{34}$ If the final constitution re-

so Much of the following draws on David Franklin, Constitutional Developments in the Czech and Slovak Federative Republic, November 1989-February 1991 (Working Paper, Center for the Study of Constitutionalism in Eastern Europe, The University of Chicago Law School, Mar 1991), and on Lloyd Cutler and Herman Schwartz, Constitutional Reform in Czechoslovakia: E Duobus Unum?, 58 U Chi L Rev 511 (1991).

31 The final Slovak draft was presented to the Federal Assembly on March 4.

32 Before 1989, the Communist Constitution was utterly unimportant, with no power to constrain behavior. Ironically, it only became important in the process of abolishing communism.

ss As further discussed below at notes 76-77 and accompanying text, the Slovaks are also resorting to bargaining based on the threat of secession.

st For details, see Jan Obrman and Jiri Pehe, Difficult Power-Sharing Talks, Report on Eastern Europe 5 (Dec 7, 1990); Jiri Pehe, Power-Sharing Law Approved by Federal Assembly, Report on Eastern Europe 6 (Dec 21, 1990). 
tains these vague compromise phrases, the role of the constitutional courts will be enhanced-if unambiguous agreement can be reached on the competencies of the federal and republican courts. ${ }^{35}$

\section{East Germany.}

One of the twelve subcommittees of the RTT in East Germany was devoted to the drafting of a new constitution. ${ }^{36}$ The draft is in many ways similar to the West German Constitution: it proposes a federal organization, with a government protected by the principle of constructive vote of no confidence and a strong constitutional court. It differs from the West German Constitution in its strong emphasis on protection of the old, the sick, the handicapped, the unemployed, the homeless, and, uniquely, unmarried couples. Clearly, it was intended to create a Sozialstaat no less than a Rechtsstaat. Although the draft had no immediate practical consequences, it has been argued that it may serve an important role in. future German constitutional debates, somewhat like the constitution of 1848 drafted by the Frankfurt Parliament that was never implemented. ${ }^{37}$

\section{Hungary.}

The Hungarian Constitution was continuously amended throughout 1989 and 1990, until approximately 95 percent of the clauses had been rewritten. ${ }^{38}$ The revisions took place in a hurry, with little systematic intention. Any "spirit of constitutionalism" seems to have been completely absent. An important feature of the current constitution is that it stipulates a two-thirds majority not only for amendments of the constitution, but for the passage of ordinary legislation in a number of designated areas. Electoral laws, in particular, have this kind of quasi-constitutional status. The Constitution follows the German model in establishing strong constitutional courts and in requiring constructive votes of no confidence. After many complications, it was decided virtually by default (because of very low participation in a referendum on this

\footnotetext{
ss According to some observers "a fourth court might then be necessary to settle disputes that were bound to arise between the republican and federal ones." Jiri Pehe, Constitutional Court to Be Established, Report on Eastern Europe 9, 10 (Mar 15, 1991).

${ }^{38}$ Available as Verfassungsentwurf für die DDR (BasisDruck Verlag, 1990).

s2 Preuss, The (Central) Round Table in the Former German Democratic Republic at 46 (cited in note 21 ).

38 For details see Antal Adám, Tendances du développement de l'ordre constitutionnel de Hongrie (Studia Juridica Auctoritate Universitatis Pécs Publicata, 1990).
} 
issue) to have the president elected by the assembly rather than by popular vote.

6. Poland.

On December 19, 1989, Poland enacted several constitutional amendments that were necessary to bring the constitution into line with the changed economic and political realities of the country. Some obsolete clauses remained, however, perhaps by oversight. Constitutional drafts have been prepared by committees both in the Sejm and in the Senate..$^{39}$ In the fall of 1990, the Polish Parliament passed a law that requires that the new constitution be passed by two-thirds of the two houses sitting together and then submitted to a referendum. As of this writing, it is unclear whether the constitution will be passed by the current parliament or the one that will emerge from the elections later this year. Most probably, the latter solution will be chosen.

\section{Romania.}

The Constituent Assembly had its first session on July 11, 1990. If the Assembly has not adopted a constitution within nine months of that date, the president can dissolve it with the approval of the prime minister and of the presidents of the two houses of the Assembly. If it has not adopted a constitution within 18 months of that date (that is, by January 1992), the president is under an obligation to dissolve it.

The constitutional committee in parliament has 23 members, of whom 13 come from the National Salvation Front. There are two subcommittees: one on rights and liberties, and one on the organization of the state. The committee presented its preliminary theses on November 14, 1990. It is in many respects an unprofessional document: eclectic, verbose, rhetorical, and excessively detailed. It is also one of the most illiberal constitutional drafts presented so far in any Eastern European country, confirming the general impression that Romania forms the rear guard in the transition to democracy and that a "second transition" may be needed. The most hotly debated issue is the proposal by the majority on the committee to prohibit political parties "founded exclusively on ethnical, religious or language criteria," a clause that would ex-

so For details on the draft of the committee in the Sejm, see Andrzej Rapaczynski, Constitutional Politics in Poland: A Report on the Constitutional Committee of the Polish Parliament, 58 U Chi L Rev 595 (1991). 
clude the Hungarian Democratic Federation (the largest opposition party).

\section{Yugoslavia.}

Once again, Yugoslav developments do not lend themselves to easy summary. The nation made timid constitutional changes in November 1988 at the federal level. ${ }^{40}$ In 1989-90, the federal presidency, the federal government, and three of the republics (Bosnia, Croatia, and Slovenia) prepared constitutional drafts for the federation. In addition to the federation, the country contains eight other potential constitution-making bodies: the six republics and the two autonomous provinces of Kossovo and Voivodina. Until 1989 , the latter two had the anomalous and near-contradictory status of being both part of the republic of Serbia (their assemblies must approve any changes in the Serbian Constitution) and represented on a par with Serbia in the collective Federal executive and (although with smaller representation) in the Federal Assembly. (As constitutions never mattered under communism, this contradiction had no consequences.) In March 1989, the Serbs abolished the independence of Kossovo through what can best be described as a constitutional coup. In July 1990, the (then illegal) parliament of Kossovo voted a new constitution that made Kossovo into a separate republic of Yugoslavia. The situation remains fluid, if not chaotic.

After adopting the requisite constitutional changes, Croatia held its first multi-party elections in April 1990. On December 21, 1990, the new Croatian assembly adopted the new Constitution of Croatia, described as a semi-presidential system of government. On February 21, 1991, Croatia declared by a constitutional amendment that all federal laws are invalid on its territory unless they accord with the Croatian Constitution. Shortly thereafter, the government of the self-proclaimed Serbian autonomous province Krajina in Croatia declared Croatian laws invalid on its territory unless they accorded with the Federal Constitution and with its own regulations. ${ }^{41}$

\footnotetext{
to Much of the following draws on Branko Smerdel, Constitutional Developments in Croatia and Yugoslavia 1989-91 (Working Paper, Center for the Study of Constitutionalism in Eastern Europe, The University of Chicago Law School, Feb 1991).

41 I know little about constitutional developments in the other republics and provinces. More generally, the paucity of references to Yugoslovia in the following exposition reflects both my lack of knowledge about this country and the extreme volitility of the situation there.
} 
B. The Issues

It is important to distinguish between constitutions and constitutionalism. The former is a written document; the latter is a state of mind-an expectation and a norm-in which politics must be conducted in accordance with standing rules or conventions, written or unwritten, that cannot be easily changed. Within the constitution, this spirit of constitutionalism is especially reflected in the stringency of the amendment procedures and the extent of checks and balances. Constitutions may exist without constitutionalism, if they are perceived mainly as policy tools or as instruments for short-term or partisan interests. Conversely, constitutionalism may exist without a written constitution, if the unwritten rules of the game command sufficient agreement. Great Britain is a good example of the latter situation, for although it has no written constitution, it is often argued that it has an unwritten one. ${ }^{42}$ Also, unwritten constitutional conventions may exist in addition to the written constitution, and supplement it on various points. ${ }^{\mathbf{4 3}}$

A constitution, considered as a written document, serves three interrelated functions: to define and protect the rights of the citizens, to establish the machinery of government, and to regulate changes in the constitution itself. I shall consider these in turn as they relate to constitutional debates in Eastern Europe.

1. Rights and freedoms.

As a general remark (there are exceptions), many of the clauses on individual rights in the Eastern European constitutions or bills of rights have two disturbing features. First, they often contain the clause that a certain right is guaranteed "unless the law provides otherwise" or "unless limited by law." Americans distrust such caveats; they place their trust in the judiciary, not the legislature. Europeans, by contrast, prefer the discretion of a parliament to that of a judge who may be under the control of the executive. ${ }^{44}$ The implied claim that the judiciary in these countries

12 Vernon Bogdanor, Britain: The Political Constitution, in Vernon Bogdanor, ed, Constitutions in Democratic Politics 53 (Gower, 1988). It has been argued that the violations of this unwritten constitution under Mrs. Thatcher have created the need for a formal bill of rights. Larry Siedentop, Thatcherism and the Constitution, Times Lit Supp 88 (Jan 26, 1990).

43 In Norway, for instance, the principle of parliamentarism is part of the unwritten constitution. The written constitution nowhere mentions the mode of appointment of the prime minister or the principle of ministerial responsibility to parliament.

4. For a more detailed discussion of this idea, see Cutler and Schwartz, 58 U Chi L Rev at 538-44 (cited in note 30 ). 
is less than fully independent is borne out in several cases. In Hungary, for instance, the former Minister of Justice Kálmán Kulcsár complained that he had difficulties weaning his officials of the habit of assigning "reliable" judges to "delicate" cases."

Second, freedom of speech, assembly, and religion are often limited by considerations of public health, public morality, and public security ${ }^{46}$ (and by the freedoms and rights of others). The link between religion, public morality, and public health seems especially mysterious. The Romanian restriction of freedom of religion by considerations of public morality is apparently motivated by the existence in nearby Moldavia of religious orders that practice and advocate licentious sexual behavior. Restrictions by considerations of public health may be an indirect way of outlawing Islam and Judaism, which practice fasting and circumcision. ${ }^{47}$

As far as specific rights are concerned, issues of language, ethnicity, and nationalism loom large. The Bulgarian drafts seem to be the most illiberal ones, with the Romanian as a close runnerup. In Bulgaria, minorities are only assured the right to be taught their own language, as distinct from the more usual right to be taught in their own language. Among the elite, there seems to be a universal consensus that it would be too dangerous to allow the Turkish minority to form a separate party, because of expected claims for secession and alliance with Turkey. Although it might be even more dangerous to deny them political rights, and thus create an oppressed minority waiting for Turkish liberation, this view does not seem to have a constituency. The idea that political rights ought to be granted to everyone regardless of such conjectural consequentialist arguments is even more foreign. In the Romanian constitutional draft, the clause on freedom of speech

45 Kulcsár made the comment at the conference on constitutionalism and the transition to democracy in Eastern Europe, which was organized by the American Council of Learned Societies, and held in Pécs, Hungary, June 1990. One solution to this problem might be to have judges assigned randomly to cases. It might even be worth putting this principle into the constitution.

4 These observations apply to the Romanian constitutional draft, to the Czechoslovak Bill of Rights, and to the constitutional draft for the Czech Republic. They do not apply to the constitutional draft for the Slovak Republic or to the Hungarian constitution.

${ }^{4}$ Although I have no direct information about the Bulgarian drafts in this respect, the following observation may be relevant. In Bulgaria, "there are . . . public campaigns directed at two religious practices which, though phrased in terms of their public health implications, could easily be seen as connecting the campaign against Turkish names with an anti-Islam campaign. The government has directly called for an end to the Ramadam fast and ritual circumcision, calling the former 'A Means of Crippling the Individual,' while describing the latter as 'Criminal Interference with Children's Health.' " Robert J. McIntyre, Bulgaria: Politics, Economics and Society 73 (Pinter, 1988). 
has sinister caveats that exclude "defamation of the country and the nation" (no flag burning here!) as well as "national, ethnical and language exclusivism or separatism."

Similarly repressive provisions have been suggested in Slovakia, where proposals to make Slovak the compulsory language in dealing with the administration had to be withdrawn when it was pointed out that such a clause would violate the Copenhagen convention and preclude membership of Czechoslovakia in the Council of Europe..$^{48}$ Later, an agreement on the competencies of the federation and the republics was reached that shifted responsibility over national and minority affairs to the federal government. ${ }^{49}$

Economic rights are also provided for in all constitutions and constitutional drafts, notably the right to hold private property and to "full" or "fair" compensation in case of expropriation. The main exception seems to concern the right to landed property. When the land is given back to the original owners in Bulgaria and Albania, for example, it may take the form of a perpetual and inheritable lease from the state rather than property in fee, which would give the feeholder the right to sell the land.

In addition, even though private property is guaranteed, the right to free entry is not. Only the Hungarian constitution explicitly says that the country "has a market economy." More generally, none of the Eastern European countries has fully confronted the complex and near-contradictory relations that obtain between economic development and constitutional democracy..$^{50}$ Constitutional guarantees against confiscation and retroactive taxation are needed to stabilize expectations and create the conditions for long-term investments. To be credible such guarantees cannot be imposed dictatorially, as a dictator can always undo by decree what he has established by decree. Barring exceptions (Chile under Pinochet is often cited as a counterexample), constitutions need democratic backing to be credible. On the other hand, democracy can also be expected to create obstacles for economic development, and the electorate may turn away from the parties that advocate economic hardship and sacrifice as a necessary first step towards growth.

Most countries will look to affirmative rights rather than the market economy to provide economic security for their popula-

4 Jan Obrman, Language Law Stirs Controversy in Slovakia, Report on Eastern Europe $13-14$ (Nov 16, 1990).

4P Pehe, Power-sharing Law Approved by Federal Assembly at 9 (cited in note 34).

so Elster, When Communism dissolves (cited in note 4). 
tions. The majority of the constitutions affirm positive welfare rights for the citizens, although often in terms too vague to be en- . forceable. The Hungarian constitution simply says that "[ $t]$ he Republic of Hungary sees to the wants of the needy through a long line of social measures." The Slovak draft constitution affirms that everyone has a "right to a standard of living commensurate to his potential and that of society as a whole." The Czech constitutional draft ensures both the right to work and the right to "adequate security" in case of "involuntary unemployment" (which the right to work is supposed to prevent). The Czechoslovak bill of rights says that "[t]he State shall provide appropriate material security to those citizens who are unable without their fault to exercise [the right to acquire the means of his or her livelihood by work]." The Romanian draft is more concrete, in that it mentions a minimum wage and the right to unemployment benefits. A proposal for a minimum wage has also been debated in Poland. The Albanian draft stipulates the right to unemployment benefits.

To summarize, the most controversial rights-related issues promise to be the rights of minorities, the right to free alienation of property, the right to a decent standard of living, and the restrictions imposed on the freedom of speech, assembly, and religion. ${ }^{51}$ The more general question is whether the legislatures and courts in Eastern Europe will adopt an attitude toward rights that is both non-instrumental, thus rendering rights immune to considerations of political expediency, and non-exhortatory, thus enabling them to be enforced in courts.

\section{The machinery of government.}

The Eastern Europeans have a rich and diverse menu from which to choose when they draft the constitutional provisions dealing with the machinery of government. Among other things, the drafters must consider issues of electoral procedures, separation of powers, checks and balances, and federalism. Then they must choose the particular devices-bicameralism or unicameralism, majority vote or proportional vote, presidential or parliamentary system, and so on-that will work best in their country. Some combinations of devices and systems are logically impossible;

61 In addition, a woman's right to choose to have an abortion may well become an issue. The provisional Czechoslovak Bill of Rights says that "human life deserves protection even before birth"-a compromise formulation between opponents and advocates of abortion. The Czech and Slovak Republics may well adopt different attitudes on this issue, and it will then be up to the constitutional court to decide. 
others obviously unstable; still others may work in some countries and not in others; and some may work in almost all countries (although not be very good in any). ${ }^{82}$ More relevantly for the present purposes, only a subset of the conceivable constitutional packages is on the agenda in Eastern Europe. Given that things are very much in flux, it is hard to generalize. Some propositions, however, can probably be justified.

None of the countries will choose the American model, with a president and no prime minister. Nor are there any proposals for an outright imitation of the French system, in which the prime minister and a strong, popularly elected president may belong to different political parties. ${ }^{58}$

All countries seem to favor the German model of judicial review, based on a powerful constitutional court.

All countries will probably adopt the constructive vote of no confidence. Under this system, parliament cannot express lack of confidence in the cabinet unless it simultaneously designates a new prime minister. This principle-designed by C.J. Friedrich for the German Constitution of $1848^{54}$ - has a stabilizing effect on government by preventing irresponsible behavior by parliament.

Proportional voting with thresholds is somewhat more likely to prevail than single-district majority voting. The thresholds might be national, or in the federally organized countries, republican only. In the 1990 Czechoslovak elections, for example, a party needed 5 percent in one of the two republics to be represented in Parliament. For the purpose of favoring the formation of national parties, national thresholds are obviously preferable.

Finally, all countries will probably vest more than merely symbolic and representative powers in the presidency. As a very rough generalization, powers of the presidency may be expected to grow as we move from West to East, although Poland may provide a counterexample.

\footnotetext{
52 My criteria for what "works" are 1) that no actor or institution can usurp power; and 2) that the system is able to make decisions and stick to them. Or, to put it negatively, that the system avoids both tyranny and deadlock. Juan Linz has suggested to me that there are three criteria: 1) that the government has an opportunity to govern; 2) that the people have an opportunity to control; and 3) that those who bring the government down must pay a price for doing so.

ss Note that a discrepancy in the party affiliation of the president and the prime minister may come about either because the periods of election differ or because voters vote for a presidential candidate different from the one promoted by the party they favor. The Albanian proposal, described above, falls in the first category. See Part III.A.1. The French system belongs to both.

s4 Merkl, The Origin of the West German Republic at 81-82 (cited in note 1).
} 
As a more vulnerable generalization, the countries seem to look in equal parts to France and to West Germany, the former providing them with a model of a strong presidency, and the latter with a model for a strong.government (due to the constructive vote of no confidence) and a strong constitutional court. Strong parliamentary regimes, therefore, are somewhat unlikely to emerge.

\section{Amendment procedures.}

The procedures for revising the constitútion are closely connected with the general spirit of constitutionalism. ${ }^{55}$ The more difficult it is to change the constitution, the more people tend to view it as a given framework for action rather than as an instrument for action. Of course, the people may also come to see it as an insupportable prison, thus there is a.need for an optimal degree of rigidity of the constitution. (As constitutional lawyers say, the constitution is not a suicide pact.) In Eastern Europe, the general tendency seems to be toward majoritarianism - be it in a presidential or parliamentary form-rather than constitutionalism. ${ }^{\text {s6 }}$ Legitimacy is vested in a parliament elected by majority vote or in a directly elected president, not in standing rules.

To strike the right balance between rigidity and flexibility, a number of devices can be used, singly or in combination. First, one can require qualified majorities for changes in the constitution. The purpose is to guard against instability, thus ensuring that the constitution remains unaffected even if majorities fluctuate between 49 and 51 percent. ${ }^{57}$

Second, one can impose delaying or "cooling" devices. For example, a system could require that changes be passed by two successive parliaments. The purpose of this solution is especially close to the spirit of constitutionalism: delays protect society against itself, by forcing passionate majorities, whether simple or qualified, to cool down and reconsider. ${ }^{\circ 8}$

so See notes 43-44 and accompanying text. For a discussion of amendment procedures, see Jon Elster, Intertemporal Choice and Political Theory, in George Loewenstein and Jon Elster, eds, Choices over Time (Russell Sage, forthcoming 1992).

${ }^{s 8}$ I am indebted to Wiktor Osiatynski for this formulation.

${ }_{57}$ Another effect of qualified majorities may be to eliminate the problem of cyclical majorities. If we assume Arrow's condition of unlimited domain, qualified majorities do not eliminate the problem of cycling. If, however, we impose certain weak constraints on the admissible combinations of individual preferences, qualified majorities prevent cycles from arising. Andrew Caplin and Barry Nalebuff, On 64\% Majority Rule, 56 Econometrica 787 (1988).

ss If we limit ourselves to qualified majorities and delays in non-federal systems, Nor- 
Third, federally organized countries can require that any changes be passed by all, or a qualified majority, of the republics. The purpose is to protect the individual republics against the federal government. (As in the United States, this solution may also serve as a delaying device.)

Fourth, constitutional changes may be taken out of the hands of parliament and be delegated to specially convened assemblies. The purpose is to prevent the legislative assembly from being judge in its own cause, and to shift the amendment power to an independent body with no special interests to defend or promote. Fifth, changes might have to be approved by referendum, perhaps with a qualified majority. This solution serves much the same purpose as the previous one. Finally, some clauses may not be subject to amendment at all. The purpose of such unamendable clauses is, I believe, mainly symbolic.

In the current constitutional debates in Eastern Europe, only the qualified majority and republic approval solutions are seriously discussed. With the exception of two of the more marginal Bulgarian drafts, delaying devices are not advocated. Under the current, rapidly changing circumstances, this neglect is probably unavoidable and, in fact, desirable. For these societies, it could be disastrous to become locked into a set of institutions that do not fit their needs. One has to be aware, however, of the dilemma thus created. The constitution will lose many of its desirable properties-notably that of inspiring confidence and creating a climate in which investors are willing to make long-term investments-if everyone expects that it will be continually revised. One might object that the clauses that are necessary to inspire confidence need not be among those actually subject to this constant revision. However, the very fact that they are relatively unprotected might in itself destroy confidence. In any case, the constitution is a whole that exercises its effects on society as a bloc, not through its individual parts.

\section{The Constitution-making Process}

To understand the emerging constitutions in Eastern Europe, we must study the process by which they come into being: the

way has both; Sweden only the latter; Hungary only the former; and New Zealand has neither. See Joseph Jaconelli, Majority Rule and Special Majorities, Public Law 587 (Win 1989); Julian N. Eule, Temporal Limits on the Legislative Mandate: Entrenchment and Retroactivity, 1987 Am Bar Found Res J 379, 415-19. 
forces that shape the constituent assembly and the processes in the assembly that shape the constitution. ${ }^{50}$

\section{Creating the assembly.}

First, a constituent assembly has to be set up, whether by election (Albania, Bulgaria, Romania) or by self-constitution (Poland, Hungary, Czechoslovakia). The genesis of the constituent assembly may be crucial for its legitimacy and for the legitimacy of the document produced. With a suitably democratic pedigree, the constitution stands a better chance of being ratified and respected. However, the case of Hungary shows that a democratically-elected constituent assembly is not a necessary condition for the production of a relatively uncontested constitution. Most of the provisions in the current Hungarian constitution were adopted before the first free elections on March 25, 1990. Unlike what happened in Czechoslovakia, there was no pre-election purge of communist members of the assembly. Nevertheless, to my knowledge no objections have been made to the constitution based on the make-up of the enacting body.

In Poland, the situation is more ambiguous. In this case, too, pre-election purges were eschewed. The former communists still form a majority in the Sejm, and even dominate the subcommittee on institutional affairs of the committee that is charged with drafting the constitution. Fears that their presence might bias the outcome of the committee proved unfounded, however, as the expert advisers did most of the work. ${ }^{60}$ (As the members of the Senate were chosen in free elections, one might expect the draft of the Senate subcommittee to enjoy greater prominence than that of the Sejm. Interestingly, the Senate committee did not play an important role. ${ }^{61}$ ) The process illustrates the importance of technical competence in modern constitution-making, to the point where it may become not just a necessary but even a sufficient condition for having influence. ${ }^{62}$ At one point, Bronislaw Geremek, the chair of

${ }^{38}$ The following discussion draws extensively on Elster, The Constitution-Making Process (cited in note 8).

${ }^{80}$ This passage draws on Rapaczynski, $58 \mathrm{U}$ Chi L Rev at 602-04 (cited in note 39).

${ }^{61}$ See id at 602.

${ }^{62}$ It is interesting to note that the constituent committee of the Spanish assembly in 1977 deliberately chose not to create an advisory group of experts. José Pedro Pérez-Llorca, Commentary, in Robert A. Goldwin and Art Kaufman, eds, Constitution Makers on Constitution Making 266, 272 (AEI, 1988). It is widely agreed that the Spanish constitution is deficient from a technical point of view, with a number of verbose and ambiguous clauses. Bonime-Blanc, Spain's Transition to Democracy at 87, 97, 103 (cited in note 2); Francisco Rubio Llorente, The Writing of the Constitution of Spain, in Goldwin and Kaufman, eds, 
the Sejm's constitutional committee, argued that the new constitution might also be adopted by the current legislature. "Some people say that this parliament should not create the new constitution. Nonetheless, I think that if [this parliament] has adopted 100 laws to change the system, then it has the legitimacy to adopt the constitution as well." ${ }^{\prime 33}$ It seems more likely, however, that the constitution will be adopted by the next legislature, because of the ambiguities still attached to the sitting one.

In Czechoslovakia, the pre-election assembly obtained the necessary legitimacy by purging itself of some 100 communist members and replacing them by co-optation, a procedure that was grounded in the existing constitution. In Bulgaria and Romania, the legitimacy of the constituent assemblies is weak, and the constitutions that emerge may similarly lack legitimacy. In both of these countries, elections were called so early that the opposition parties had little time to organize. Although direct fraud was probably marginal, the communists used their strong organization to browbeat ignorant voters in the countryside. In Bulgaria, the outcome was to some extent shaped by the electoral laws that were agreed on in the RTT. The dubious legitimacy enjoyed by those talks today might easily be passed along to the electoral laws, the constituent assembly, and the constitution.

\section{Decisionmaking in the assembly.}

The proceedings of the assembly can be analyzed through two distinctions. First, I shall distinguish between impartiality and interest as motives animating the constitution-makers. Second, I shall distinguish between arguing and bargaining as the two main forms of constitutional speech acts. Although it might seem that impartiality goes naturally with arguing and interest with bargaining, the reality is more complicated. A study of earlier constitution-making processes shows that all four possible combinations of these factors occur quite frequently.

Constitution Makers on Constitution Making 239, 259, 263. Had lawyers been more closely involved, the document would probably have been straightened out. It is not obvious, however, that this would have been a good thing. Sometimes, ambiguity and vagueness are essential for reaching agreement. Also, lawyers may not limit themselves to straightening out messy formulations; they may, inadvertently or deliberately, impose substantive views of their own.

es Louisa Vinton, The Debate over the "Political Calendar", Report on Eastern Europe 13 (Nov 2, 1990). 
a) Interest and impartiality. Although the distinction between interest and impartiality is clear enough in theory, it is often blurred in practice. In arguing from one of these motives, framers are often constrained by the other. Even the most impartial framers may have to anticipate and internalize the interests of the groups that are to ratify the constitution. Conversely, even the most self-interested of framers must respect the norms of impartiality and consistency that regulate public debate.

The first constraint is illustrated by the debates about the role of the Senate under the future Polish constitution. ${ }^{64}$ There may not have been any good impartial arguments for retaining this institution in the government. However, given that the Senate as an institution was very popular, and considering that it had to give its blessings to the new constitution, it was unthinkable for the subcommittee of the Sejm to simply abolish it. And in the end, the subcommitte did not propose its abolition. Assuming the subcommittee was wholly motivated by impartial concerns, it was still constrained by the interests of those who were to ratify the constitution. ${ }^{65}$

To a large extent, the subcommittee of the Sejm seems actually to have been motivated by impartial concerns. ${ }^{86}$ Although I lack reliable knowledge about what has gone on inside other constitutional committees and assemblies, I conjecture that such genuinely impartial reasoning is rare. It seems clear that the prohibition of ethnically-based parties contained in the majority draft of the Romanian constitution is aimed at the Hungarian Democratic Federation. The jockeying for electoral position that took place in the RTT of the various countries is likely to repeat itself in the constitutional debates. Large parties and parties with highly visible candidates are likely to favor majority voting or proportional voting with high thresholds. The large parties that are most likely to form a government will push strongly for a constructive vote of no confidence. Parties who have a popular presidential candidate are likely

84 The following draws on and summarizes Rapazcynski, $58 \mathrm{U}$ Chi L Rev at 614-16 (cited in note 39).

s8 At the American Constitutional Convention, several delegates argued that the constitution ought to be tailored so as to be acceptable to the state legislatures because they assumed that the legislatures would be ratifying the document. Max Farrand, ed, 1 The Records of the Federal Convention 132, 374 (Yale, 1966). Others of course successfully argued against the idea that the constitution should be ratified by the legislatures given that the legislatures stood to lose much of their power if the Constitution was adopted. Id at 123.

${ }^{68}$ See Rapacyznski, $58 \mathrm{U}$ Chi L Rev at 615-16 (cited in note 39). Note, however, that he does cite the self-interest of committee members from the old regime as the explanation for why electoral laws are not included in the draft. 
to argue for popular election of the president, whereas the other parties will vote for election by the assembly and try to limit the powers of the presidency as much as possible.

With respect to the last issue, the current Polish debates over the powers of the president may be seen as a reenactment of the 1919-21 constitutional Sejm. At that time, it was widely expected that Joseph Pilsudski would be elected president under the new constitution. Perceiving Pilsudski both as a socialist and as a strong personality, the conservative Sejm wrote a weak presidency into the constitution-so weak, in fact, that Pilsudski, preferring to bide his time, refused to stand for election. Today, one school of thought argues that the Poles, fearing the strong personality of President Walesa, will write a weak presidency into the new constitution. Others argue that the assembly, being under the pressure of that strong personality, will accommodate him by giving him large powers. Similarly ambiguous feelings may exist with respect to President Havel in Czechoslovakia.

However, these self-interested arguments are constrained by the norm of impartiality. In one sense, the idea of self-interested argument is meaningless. Arguments have to be stated in impartial terms, as if one were arguing for the public good and not for one's own self-interest. To persuade others that society ought to be organized so as to accommodate a particular set of private interests one must either back the claim by a credible threat or argue that this arrangement will in fact serve a more impartial end that commands general acceptance. One cannot say, "I want this outcome because it is good for me," and expect others to be persuaded. There simply is no language game of that kind. When I refer to a self-interested argument, therefore, I have in mind utterances whose ultimate but unstated motivation is the self-interest of the speaker. That motivation may be transparent to others, but it cannot be stated.

Consider again the choice between proportional and majority voting. On the one hand, proportional voting can be backed by powerful arguments from democratic theory and the rights of the electorate. On the other hand, majority voting tends to yield more stable and efficient government. Similarly, there are strong fairness arguments both for equal representation and proportional representation of the states in a federal system. ${ }^{67} \mathrm{~A}$ proposal for a con-

\footnotetext{
67 At the Federal Convention, one delegate argued that any scheme that would give some states no representation in the Senate would be "unfair." Farrand, ed, 1 Records of the Federal Convention at 159 (cited in note 65). James Madison argued that any deviation from proportional representation was "unjust." Id at 151.
} 
stitutional clause that could have no other justification besides that of favoring one party would not be taken seriously-as long as we are in the context of public discussion rather than private bargaining.

b) Rhetorical use of historic and contemporary constitutions. Impartial arguments-whether genuine or spurious-are of two kinds: rights-based and efficiency-based. Arguments for proportional voting, for instance, typically appeal to rights, whereas arguments for majority voting invoke the need for stable and efficient government. I shall not discuss the variations on these two kinds of argument, but focus on one issue that is especially relevant for Eastern Europe: how can constitution-makers assess the consequences of various institutional arrangements? One answer is that because we cannot know, we should assume the worst. Another-the one I shall pursue here-is to look to contemporary and earlier constitutions to find out what seems to work. In constitutional debates, one invariably finds a large number of references to other constitutions, as models to be imitated, as disasters to be avoided, or simply as evidence for certain views about human nature. ${ }^{68}$

Consider first the rhetorical use of the past. In most Eastern European countries today, there is a tendency to look to the precommunist constitutions as sources of inspiration. ${ }^{69}$ These earlier documents may serve as focal points; they allow the constitutionmakers to single out the most salient among the innumerable models that could be adopted. They may serve as a source of experience that is particularly relevant because of the sociological continuity with the past. They may be used symbolically, to affirm the continuity of the nation over time. Finally, they may be used as rationalizations of conclusions reached on other grounds. Those who cite the existence of a Polish Senate in the pre-communist constitution as an argument for writing it into the new one may in reality be moved by tactical and partisan concerns.

\footnotetext{
s8 For these distinctions, see Morton White, Philosophy, The Federalist, and the Constitution ch 4 (Oxford, 1987).

${ }^{89}$ For a discussion of the role of the past in Hungarian constitutional developments, see Kálmán Kulcsár, Old Constitutions and the New Ones: The Problem of Continuity of Constitution in East-Central Europe 14-33 (paper for colloquium "Learning from the Past: Constitutionalism in Eastern Europe," Norwegian Academy of Science, Dec 1990) (on file with U Chi L Rev).
} 
Consider next the use of contemporary models. ${ }^{20}$ The countries in Eastern Europe strongly feel the pull of the constitutions in Western Europe, especially those of France and Germany that are widely regarded as very successful. Because of geographical proximity, the Albanians are also looking toward Greece and Italy. There is a danger, however, that some of these countries may end up writing their constitutions a la carte, believing they can take the best from each of several constitutions and ignoring the fact that constitutions have their effect through the totality of interlocking clauses rather than through their individual parts. ${ }^{71}$

Impartial arguments based on both historic and contemporary constitutional models have yielded a variety of results in Eastern Europe. In Albania, for instance, the trend seems to be toward a strong president (French model) elected by the assembly (German model). It is not at all clear that this system could work under all circumstances. However, the dangers of eclecticism do not provide an argument for the wholesale adoption of another constitution. Because of differences in the extra-constitutional environment, an arrangement that works well in one country can be disastrous in another, as shown by the failed attempts to transplant the United States Constitution to other countries.

A fairly robust generalization seems to be that constitutionmakers are more influenced by past disasters than by past successes. The Framers in Philadelphia had learned a great deal from the pathologies of the various state constitutions. The constitution of the Fifth French Republic was explicitly designed to prevent the parliamentary chaos that had reigned under the Fourth. The West German framers in 1948 "looked at the Weimar era in the same light in which the fifty-five men at Philadelphia regarded the years following the War of Independence: as a period of anarchy during which the governmental institutions had fallen too much under the sway of popular whim and fancy," costs. The main reason why these recent failures matter so much seems to be that they guide the construction of worst-case scenarios. Caution comes naturally to many constitution-makers. However, there are a great many bad things that could happen-chaos, tyranny, deadlock. Recent failures have the effect of lending spe-

\footnotetext{
${ }^{20}$ On the general issue of legal (not just constitutional) borrowing, see Eric Stein, Uses, Misuses-and Nonuses of Comparative Law, 72 Nw U L Rev 198 (1977).

71 This statement is somewhat exaggerated. The various rights are to a large extent independent of each other.

${ }^{2}$ Merkl, The Creation of the West German Republic at 81 (cited in note 1).
} 
cial salience to one of these scenarios. In Eastern Europe, one might think that memories of communism would single out the fear of a strong executive as the most potent one. Although there are some signs of this effect, notably in Hungary, it does not appear to be universally present.

c) Arguing and bargaining. To argue is to engage in communication for the purpose (or apparent purpose) of persuading an opponent, i.e., to make the other change his beliefs about factual or normative matters. Statements asserted in a process of arguing are made with a claim to being valid. To bargain is to engage in communication for the purpose of forcing or inducing the opponent to accept one's claim. To achieve this end, bargainers rely on threats and promises, to be executed within or outside the assembly itself. Bargaining power does not derive from the power of the better argument, but from material resources, manpower, votes, and the like. Statements asserted in a process of bargaining must be credible; bargainers must try to make their opponents believe that they would carry out any threats or promises that they make. In the category of bargaining I also include disguised threats and pseudo-warnings, as defined above.

We may distinguish between intra-constituent bargaining or logrolling, and extra-constituent bargaining based on resources other than votes. Logrolling is a form of exchange, in which each party makes a concession on a less valuable issue to gain on one that matters more to him. ${ }^{73}$ It is also a form of bargaining, since it is based on the threat of voting according to one's preferences on one issue unless the other side votes against his preferences on another. Extra-constituent bargaining makes essential reference to events outside the constituent assembly, by stating one's intention to harm the other party, in his purse or body or otherwise, unless certain demands are satisfied.

An example of logrolling in Eastern Europe was a deal reputed to have been struck in Yugoslavia: Croatia and Slovenia would abstain from interfering with Serbian repression in Kossovo if the Serbs would let them go their way to independence. It would be surprising if such exchanges did not play a major role in the closed

${ }^{73}$ Logrolling might be defined more broadly. Thus Brian Barry, Political Argument 318 (Humanities, 1965), includes the case of "rational egoists [who] would, under a unanimity system, misrepresent their preferences and commit themselves to vote against things they really wanted in order to get a bribe as well." I shall assume, however, that preferences are known. 
sessions that are now taking place in other Eastern European capitals. By the nature of the case, however, hard evidence is hard to come by. ${ }^{74}$

Extra-constituent bargaining can be bilateral or unilateral. In bilateral bargaining, each of two sides has extra-constitutional forces at its disposal. For example, the Round Table Talks in Hungary and Poland were torn between the fear of Soviet intervention and the risk of mass demonstrations. Today, many of the Eastern European countries are caught between the demands of the international community on the one hand and popular nationalism and opposition to foreign ownership on the other. If they do not write a full set of human rights into their constitutions they will be denied membership in the Council of Europe, and membership is a de facto condition for aid from the Economic Community. If they do not write strong guarantees for property and contract into their constitutions, they may not get assistance from the International Monetary Fund. Some of the political actors may deliberately play on these international bodies, by issuing warnings (or pseudowarnings?) about the disastrous effects of yielding to popular demands. Other actors may equally deliberately play on the fear of mass demonstrations, by issuing warnings (or disguised threats?) that rigorous policies will unleash popular riots. ${ }^{75}$

In Czechoslovakia, we find unilateral extra-constituent bargaining using the threat or warning of secession. As mentioned earlier, Slovakia has been able to obtain parity of power in many parts of the federal system as well as considerable autonomy for the republic. To say, as I did, that these results have been obtained because the country retained the communist constitution is true, but insufficient, because we must also explain why the rules of the game were not changed to reflect the demographics of the country.

74 Logrolling is a form of across-issue compromise. Within-issue compromise, illustrated by the electoral laws in Bulgaria and Hungary, is also important. In explaining the form within-issue compromises take, extra-constituent factors are often important. At the Federal Convention, the Connecticut Compromise was not the only possible one. Proposals were also made to strike a compromise within the Senate itself, by which the representation of the smaller states would go beyond proportionality but fall short of equality. Farrand, ed, 1 Records of the Federal Convention at 405, 488-89, 510-11 (cited in note 65). A system of this kind was actually adopted in the West German constitution of 1948. In The Constitution-Making Process (cited in note 8), I argue that extra-constituent bargaining power could explain why the small states obtained full rather than truncated equality.

75 There are actually two different scenarios that could occur. In one, populist and nationalist groups play on the masses to obtain illiberal concessions. In another, democratic forces play on the masses to obtain liberal concessions. The former was illustrated by the Romanian events in June 1990, the latter by events in Bulgaria throughout 1990. 
Three explanations come to mind: the desire for a legitimate transition, the lack of time to adopt a new constitution, and the focalpoint quality of the constitution in place.

However, the most important cause may be that the Slovaks backed their demands with a threat of secession. Some political leaders in Slovakia genuinely strive for secession..$^{76}$ Other (and more responsible) politicians who do not share this goal have nevertheless used the threat of secession as a bargaining chip, and with some success. ${ }^{77}$ It is possible that the former have been the unwitting tools of the latter. The Slovak leaders who negotiated with the Czech and federal governments may have been issuing warnings rather than threats: unless you give in to our demands, the nationalist drive for secession will become irresistible. This hypothesis seems to make better sense than the threat hypothesis, as it is hard to see how a threat of secession would be credible. The question then arises whether these were genuine warnings or pseudo-warnings. In the latter. case, we may further ask whether the Slovak leaders might not find themselves in the situation of the sorcerer's apprentice. Nationalist feeling is a force that lends itself badly to fine tuning.

\section{Conclusion}

The main difficulty of the constitution-makers in Eastern Europe is that they are operating in a complete vacuum. There are no ground rules; everything is up for arguing and bargaining. The framers have too much freedom, too many possibilities to choose from, and too many decisions to make simultaneously. Even the actors have to be created, because there are so few well-organized political parties. In these countries, the metaphysical fact that any assembly is made up of individuals will also be a political reality. Two questions therefore arise. First, what are the mechanisms by which the number of alternatives might be reduced, so as to make meaningful choices possible? Second, what are the mechanisms by which the number of actors might be reduced, so as to facilitate the formation of stable coalitions?

With regard to limiting the number of alternatives, the experience of the West German Constituent Assembly in 1948 is informative, for it involved a case of constitution-making in a country

${ }^{78}$ Jiri Pehe, Growing Slovak Demands Seen as Threat to Federation, Report on Eastern Europe 1 (Mar 22, 1991).

${ }^{77}$ Pehe, Power-sharing Law Approved by Federal Assembly at 6 (cited in note 34). 
that had recently emerged from totalitarian rule. The Assembly's constitution-making was much facilitated by the fact that the occupying powers imposed the mode of election of the delegates and the mode of ratification by the Länder. The constitution-making task was also simplified by the knowledge that the occupying powers would veto any non-consensual or dogmatic proposal. The closest analogy for the Eastern European countries today is the international community. One hope for the constitution-making process is that the European Community, the Council of Europe, and the Conference on Security and Cooperation in Europe will exercise a salutary constraining influence.

In the presence of multiple alternatives, differing across multiple dimensions, choice is also facilitated if there is one uniquely salient arrangement that stands out from the others. In some Eastern European countries, the pre-communist constitutions may well assume this focal-point quality. In others, the strong pull of the German Constitution may be decisive.

With respect to limiting the number of actors, the action of the international community may prove important here as well. Social Democrat and Christian Democrat parties in Western Europe can to some extent facilitate the process of party formation in Eastern Europe. The pre-communist party structure might also serve as a matrix for party formation. The Hungarian case illustrates the fragility of this mechanism, however. ${ }^{78}$ In the long run, the choice of electoral laws will probably be the most important factor in promoting a small number of stable political parties. In the short run, however, these laws are part and parcel of the constitutional package to be adopted.

The most important obstacle to constitutionalism in Eastern Europe has already been identified above: for countries undergoing rapid social and economic change, commitment to standing rules may not be desirable. At the Federal Convention, George Mason observed that " $[t]$ hough he had a mortal hatred to paper money, yet as he could not foresee all emergencies, he was unwilling to tie the hands of the Legislature. He observed that the late war could

78 "The Independent Smallholder's Party and the Social Democratic Party are so-called historical parties that existed until 1948. The initially strong showing of both parties in the polls suggested that people welcomed their revival. Soon after they had been established, however, infighting began, primarily over the issue of personnel; many party members who had been active before 1948 wanted to monopolize important positions within the parties." Zoltan D. Barany, The State of the Parties as Elections Approach, Report on Eastern Europe 23 (Mar 16, 1990). 
not have been carried on, had such a prohibition existed."79 The future of many Eastern European countries may prove to be a succession of such emergencies, in which constitutional self-binding might be disastrous. The potentially tragic dilemma is that the future without a constitution to regulate expectations and behavior might be equally bleak.

79 Farrand, 2 Records of the Federal Convention at 309 (cited in note 65). 